\title{
Inventarisasi Tanaman Obat yang Dapat Digunakan sebagai Elemen Lansekap pada Dataran Rendah hingga Dataran Tinggi Di Kabupaten Tabanan
}

\author{
WAYAN WISNU WARDANA ${ }^{1}$, I NYOMAN GEDE ASTAWA ${ }^{1 *}$, \\ I KETUT SARDIANA ${ }^{1}$ \\ Program Studi Agroekoteknologi, Fakultas Pertanian, Universitas Udayana, Jalan P.B. \\ Sudirman, Denpasar, 80232, Indonesia \\ *E-mail: nyomangede.astawa@yahoo.com
}

\begin{abstract}
Inventory of Medical Plants used as Landscape Elements From the Lowlands to the Highlands of Tabanan Regency
\end{abstract}

Tabanan regency is one district that has lowland and highland. Besides, Tabanan still very strong Balinese culture that is still many people who use medical plants not only as a raw material cuisine, but also as an infrastructure for prayer, ritual raw materials, and also as a treatment for balian, but these plants also have beautiful stem, leaves, flowers, and fruits so it can be used as an ornamental plant or as landscape elements, especially at home, in hotels and government offices. Results from this study can be useful for people who want to know the medical plants in the area of the Tabanan regency and the suitability of areas where the growth is suitable in highland or lowland areas. Methods used in this study are literature studies, surveys, observation and identification (observation), survey using list name of plants and data analysis. Research conducted in three sub-districts such as Kediri, Marga, and Baturiti. Results indicated that, based on the altitude there was found several number of medical plants species i.e. in sub-districts of Kediri 43 species, in subdistricts of Marga 26 species, and in sub-districts of Baturiti 15 species. Medical plants in the area usually found in the garden, telajakan, or in tegalan land unit.

Keywords: landscape elements, medical plants, Tabanan regency

\section{Pendahuluan}

Penggunaan bahan alam sebagai obat tradisional di Indonesia telah dilakukan oleh nenek moyang kita sejak berabad-abad yang lalu (Sukandar E Y, 2006). Tanaman obat dewasa ini mulai semakin banyak dijual dan digunakan sebagai tanaman hias oleh para penjual tanaman hias. Tanaman obat tidak hanya memiliki khasiat sebagai bahan obat-obatan tradisional, namun tanaman tersebut juga memiliki batang, daun, bunga, dan buah yang indah sehingga dapat digunakan sebagai elemen lunak pada taman rumah. (Katno dan Pramono. 2003). Faktor paling penting dalam mengatur lahan untuk tanaman 
obat adalah memperhatikan estetika (keindahan) agar tanaman obat yang ditanam di halaman tidak merusak/mengganggu pemandangan.

\section{Metode}

\subsection{Studi Kepustakaan}

Merupakan suatu metode yang digunakan oleh penulis untuk mengetahui dan menghimpun informasi sampel dari masing-masing lokasi yang relevan dan informatif yang sesuai dengan topik serta masalah yang akan atau sedang diteliti. Jenis data ini dapat berupa data sekunder yang dapat diperoleh dari jurnal hasil penelitian, buku-buku ilmiah, laporan penelitian, tulisan ilmiah, tesis dan disertasi, ensiklopedia dan sumber-sumber tertulis tercetak maupun elektronik lain.

\subsection{Survei}

Penelitian ini menggunakan metode survei yang merupakan metode pengumpulan data dengan mendatangi langsung lokasi yang dijadikan objek penelitian. Survei akan dilakukan pada tempat yang memiliki ketinggian yang berbeda yaitu dataran rendah, dataran sedang, dan dataran tinggi.

\subsection{Pengamatan dan Identifikasi (observasi)}

Pada setiap tempat survei, semua jenis tanaman obat yang ditemukan akan diamati dan dicatat habitusnya, dicari nama lokal (Indonesia, daerah Bali), nama latin, kegunaan sebagai tanaman obat, dan kegunaan sebagai tanaman lansekap.

\subsection{Survei Menggunakan Daftar Nama Tanaman}

Survei yang dilakukan dengan cara membawa borang (daftar nama) yang telah diisi dengan nama tanaman obat yang telah diketahui di daerah Bali, sehingga keberadaan tanaman obat di tempat survei hanya dengan memberi tanda rumput pada kolom nama tanaman obat yang ada pada wilayah tersebut. (Adiputra dan Handari, 2007).

\subsection{Analisis data}

Analisis data diartikan sebagai upaya mengolah data menjadi informasi, sehingga karakteristik atau sifat-sifat data tersebut dapat dengan mudah dipahami dan bermanfaat untuk menjawab masalah-masalah yang berkaitan dengan kegiatan penelitian.

Dengan demikian, teknik analisis data dapat diartikan sebagai cara melaksanakan analisis terhadap data, dengan tujuan mengolah data tersebut menjadi informasi, sehingga karakteristik atau sifat-sifat datanya dapat dengan mudah dipahami dan bermanfaat untuk menjawab masalah-masalah yang berkaitan dengan kegiatan penelitian, baik berkaitan dengan deskripsi data maupun untuk membuat induksi, atau menarik kesimpulan tentang karakteristik populasi (parameter) berdasarkan data yang diperoleh dari sampel (statistik).

\section{Hasil dan Pembahasan}

\subsection{Pembagian Tanaman Menurut Habitus dan Kegunaan Tanaman sebagai Tanaman Obat}

Dari hasil penelitian yang dilakukan di ketiga Kecamatan (Kecamatan Kediri, Marga, dan Baturiti) didapat enam habitus tanaman obat yang terdiri dari tujuh jenis pohon besar/sedang, 33 jenis pohon kecil/perdu, 21 jenis semak, empat jenis penutup tanah, tiga jenis tanaman rambat, dan tiga jenis tanaman air. 
Menurut (Hariana, 2009) Indonesia yang beriklim tropis menyebabkan tanahnya subur sehingga banyak jenis tumbuhan yang dapat tumbuh.Beberapa jenis tanaman yang tumbuh di Indonesia memiliki khasiat sebagai obat.Namun, sebagian besar kegunaan dari tumbuhan obat itu tidak diketahui oleh masyarakat.

Berikut ini pada Tabel 1.disajkan secara rinci kegunaan tanaman sebagai tanaman obat.

Tabel 1. Kegunaan Tanaman sebagai Tanaman Obat

\begin{tabular}{|c|c|c|}
\hline No & Tanaman & Kegunaan sebagai obat \\
\hline 1 & Adas & Mengobati Sakit perut \\
\hline 2 & Alamanda & Mencegah komplikasi dari malaria dan pembengkakan limpa \\
\hline 3 & Alang-alang & Meredakan panas dalam, mengatasi sakit ginjal \\
\hline 4 & Angsana & Mengobati batu ginjal \\
\hline 5 & Anyang-anyang & Pelancar air seni, Demam, Sakit Kuning \\
\hline 6 & Awar-awar & $\begin{array}{l}\text { Obat bisul, obat luka, borok, penawar racun binatang berbisa, dan sesak } \\
\text { nafas }\end{array}$ \\
\hline 7 & Bakung & Mengobati sakit gigi \\
\hline 8 & Bayam duri & Mengobatigangguan pernafasan \\
\hline 9 & Belimbing wuluh & Pengobatan jerawat, dan obat batuk \\
\hline 10 & Bidara laut & Menyegarkan kulit muka, dan membangkitkan nafsu makan \\
\hline 11 & Bunga kuping gajah & Obat bengkak pada tenggorokan dan mulut \\
\hline 12 & Bunga kenop & Mengobati sesak napas, Radang saluran napas akut \\
\hline 13 & Bunga kotok & Obat penyakit mata, salep untuk penyembuhan luka \\
\hline 14 & Bunga pagoda & Obat radang, haid tidak teratur, tekanan darah tinggi \\
\hline 15 & Cempaka putih & Mengobati demam, pusing (vertigo), dan sakit panas \\
\hline 16 & Ceremai & Obat mual, obat asma, obat sariawan, batuk berdahak, dan sakit kulit \\
\hline 17 & Daun dewa & Mengobati luka terpukul, dan melancarkan sirkulasi \\
\hline 18 & Daun encok & Mengobati encok dan pening \\
\hline 19 & Daun katu & Memperbanyak ASI, mengobati demam, bisul, dan borok \\
\hline 20 & Daun kentut & Mengobati rematik, memperlancar kencing, batuk \\
\hline 21 & Daun mangkok & Mengobati radang payudara, dan rambut rontok \\
\hline 22 & Daun Suji & Mengobati penyakit disentri, beri-beri, kencing nanah \\
\hline 23 & Daun ungu & Obat wasir, sembelit, bisul, demam \\
\hline
\end{tabular}




\begin{tabular}{|c|c|c|}
\hline No & Tanaman & Kegunaan sebagai obat \\
\hline 24 & Gandarusa & Obat pegal linu, pening, dan haid tidak teratur \\
\hline 25 & Genjer-genjer & Sebagai obat penambah nafsu makan \\
\hline 26 & Hanjuang & Mengobati batuk darah \\
\hline 27 & Jahe & Mengobati sakit kepala, batuk, masuk angin, dan rematik \\
\hline 28 & Jarak pagar & Mengobati radang telinga, obat sakit gigi berlubang \\
\hline 29 & Kacapiring & Mengobati sariawan, demam, dan sesak nafas \\
\hline 30 & Kadaka & Obat penyubur rambut, demam, sakit kepala \\
\hline 31 & Kamboja & Mengobati radang usus (enteritis), disentri basiler \\
\hline 32 & Kapu-kapu & $\begin{array}{l}\text { Obat penyakit rematik, obat anti radang, peluruh keringat, peluruh kencing, } \\
\text { obat penyakit flu, dan demam }\end{array}$ \\
\hline 33 & Kastuba & Memperlancar haid, disentri, memperbanyak ASI (air susu ibu) \\
\hline 34 & Kelor & $\begin{array}{l}\text { Meningkatkan ketahanan alamiah tubuh, menyegarkan mata dan otak, } \\
\text { meningkatkan metabolisme tubuh }\end{array}$ \\
\hline 35 & Kembang coklat & Mengobati gangguan fungsi hati \\
\hline 36 & Kembang kertas & Mengobati bisul, dan mengatasi biang keringat \\
\hline 37 & Kembang sepatu & Mengobati demam anak, batuk, sariawan \\
\hline 38 & Kemuning & Mengobati rematik, sakit pinggang, dan Sakit gigi \\
\hline 39 & Kenanga & Mengobati nyeri haid, bahan kosmetik \\
\hline 40 & Ketapang & Mengobati panu, dan kurap \\
\hline 41 & Kol banda & Mengobati asma, bisul, bengkak, dan penebalan kulit \\
\hline 42 & Kumis kucing & Peluruh air seni, tekanan darah tinggi, encok \\
\hline 43 & Langkuas & Mengobati rheumatik, dan sakit limpa \\
\hline 44 & Lidah buaya & Mengobati radang tenggorokan \\
\hline 45 & Lidah mertua & Obat batuk, mengobati penyakit darah tinggi \\
\hline 46 & Lili paris & Menghilangkan bekas luka \\
\hline 47 & Lontar & Obat kulit (dermatitis), mengobati cacingan \\
\hline 48 & Lotus & $\begin{array}{l}\text { Mengobati batuk darah, Muntah darah, Muntah dan diare, Darah tinggi, } \\
\text { Panas dalam, dan Gondokan }\end{array}$ \\
\hline 49 & Mawar & Sebagai antikejang, Sebagai pengatur haid \\
\hline 50 & Melati jepang & Mengobati penyakit sesak napas, sakit kepala, demam, dan stres \\
\hline 51 & Nusa indah & Mencegah kanker payudara, mengobati head stroke (demam akibat udara \\
\hline
\end{tabular}




\begin{tabular}{|c|c|c|}
\hline No & Tanaman & Kegunaan sebagai obat \\
\hline & & panas), mengobati bronchitis \\
\hline 52 & Pacar cina & $\begin{array}{l}\text { Penghilang bau badan, sakit perut, luka baru, memar, bisul, darah haid } \\
\text { banyak, dan perut kembung }\end{array}$ \\
\hline 53 & Patah Tulang & Mengobatikulit tertusuk duri atau pecahan kaca \\
\hline 54 & Pisang-pisangan & Obat sakit perut \\
\hline 55 & Pulai & Obat demam, tekanan darah tinggi demam, malaria \\
\hline 56 & Pule pandak & Obat kolera, tekanan darah tinggi, obat sakit kepala, dan bisul \\
\hline 57 & Puring & Obat peluruh keringat, penguat lambung, Perut mulas \\
\hline 58 & Semanggi & Obat pilek, batuk, sariawan, kudis, eksim \\
\hline 59 & Sembung & Obat demam, batuk, melancarkan keluarnya keringat \\
\hline 60 & Sirih belanda & Mengobati batuk, dan radang saluran napas \\
\hline 61 & Sisik naga & Obat anker payudara, sakit kuning \\
\hline 62 & Songgolangit & Obat sakit perut, malaria, radang ginjal, asam urat \\
\hline 63 & Srigading & Obat demam, encok \\
\hline 64 & Tapak dara & Mengobati kencing manis, dan buang air kecil sakit \\
\hline 65 & Tapak liman & Obat mencret, batuk, sariawan, Influenza, demam \\
\hline 66 & Tembelekan & Obat batuk, obat luka, peluruh air seni, dan obat bengkak \\
\hline 67 & Teratai & Mengobati gangguan penyerapan makanan, diare \\
\hline 68 & Waru & Mengobati demam, bisul, dan amandel \\
\hline 69 & Widuri & Mengobati kaki pegal dan lemas, dan bisul \\
\hline
\end{tabular}

\subsection{Jenis Tanaman Obat yang Paling Banyak Ditemukan di Masing-masing Lokasi}

Di ketiga lokasi survey, pada dataran rendah (Kecamatan Kediri), dataran sedang (Kecamatan Marga), dan dataran tinggi (Kecamatan Baturiti) ditemukan beberapa jenis tanaman yang sama yang didapat di berbagai tempat seperti di telajakan, kebun, dan tegalan.

Berikut ini pada Tabel 2.disajikan secara rinci tanaman-tanaman yang banyak ditemukan di lokasi survei. 
Tabel 2. Tanaman yang Ditemukan pada Masing-masing Lokasi

\begin{tabular}{|c|c|c|c|c|c|}
\hline No & Kecamatan & Letak & Nama Tanaman & $\begin{array}{c}\text { Banyak } \\
\text { Lokasi } \\
\text { yang } \\
\text { Ditemukan }\end{array}$ & Jumlah Tanaman \\
\hline 1 & Kediri & Kebun & $\begin{array}{l}\text { Kembang coklat } \\
\text { Kembang kertas } \\
\text { Bakung } \\
\text { Puring } \\
\text { Widuri } \\
\text { Melati jepang } \\
\text { Daun mangkok } \\
\text { Sambung tulang } \\
\text { Lidah mertua } \\
\text { Tapak dara } \\
\text { Hanjuang } \\
\text { Angsana } \\
\text { Kol banda } \\
\text { Daun dewa } \\
\text { Lili paris } \\
\text { Mawar } \\
\text { Kastuba } \\
\text { Kamboja } \\
\text { Ketapang } \\
\text { Lidah buaya } \\
\text { Bayam duri } \\
\text { Kelor } \\
\text { Kemuning } \\
\text { Langkuas } \\
\text { Jahe } \\
\text { Lotus } \\
\text { Pisang-pisangan } \\
\text { Kembang sepatu } \\
\text { Adas } \\
\text { Kadaka } \\
\text { Alamanda } \\
\text { Daun dewa } \\
\text { Kuping gajah } \\
\text { Lidah buaya } \\
\text { Lontar } \\
\text { Kastuba } \\
\text { Daun suji } \\
\text { Jarak pagar } \\
\text { Kamboja } \\
\text { Kapu-kapu } \\
\text { Kembang kertas }\end{array}$ & $\begin{array}{c}3 \\
2 \\
3 \\
11 \\
3 \\
2 \\
1 \\
4 \\
10 \\
1 \\
9 \\
3 \\
2 \\
5 \\
11 \\
3 \\
2 \\
1 \\
3 \\
9 \\
12 \\
2 \\
3 \\
1 \\
9 \\
2 \\
1 \\
3 \\
1 \\
3 \\
2 \\
5 \\
2 \\
4 \\
2 \\
4 \\
1 \\
2 \\
12 \\
2 \\
10\end{array}$ & $\begin{array}{c}11 \\
3 \\
5 \\
78 \\
4 \\
5 \\
3 \\
5 \\
115 \\
1 \\
50 \\
3 \\
4 \\
15 \\
144 \\
3 \\
2 \\
1 \\
3 \\
31 \\
12 \\
7 \\
4 \\
8 \\
119 \\
13 \\
8 \\
8 \\
40 \\
5 \\
2 \\
12 \\
5 \\
8 \\
3 \\
5 \\
6 \\
11 \\
23 \\
34 \\
14\end{array}$ \\
\hline
\end{tabular}




\begin{tabular}{|c|c|c|c|c|c|}
\hline \multirow[t]{2}{*}{ No } & Kecamatan & Letak & Nama Tanaman & $\begin{array}{c}\text { Banyak } \\
\text { Lokasi } \\
\text { yang } \\
\text { Ditemukan }\end{array}$ & Jumlah Tanaman \\
\hline & & Tegalan & $\begin{array}{c}\text { Kelor } \\
\text { Pacar cina } \\
\text { Daun kentut } \\
\text { Daun mangkok } \\
\text { Langkuas } \\
\text { Jahe } \\
\text { Pisang-pisangan } \\
\text { Tapak dara } \\
\text { Alang-alang } \\
\text { Belimbing wuluh } \\
\text { Bidara laut } \\
\text { Genjer-genjer } \\
\text { Bayam duri } \\
\text { Daun suji }\end{array}$ & $\begin{array}{c}1 \\
2 \\
2 \\
10 \\
2 \\
3 \\
2 \\
1 \\
5 \\
2 \\
7 \\
4 \\
15 \\
3\end{array}$ & $\begin{array}{c}2 \\
2 \\
2 \\
11 \\
11 \\
33 \\
11 \\
1 \\
136 \\
2 \\
11 \\
19 \\
15 \\
8\end{array}$ \\
\hline \multirow[t]{3}{*}{2} & Marga & Telajakan & $\begin{array}{c}\text { Melati jepang } \\
\text { Sangga langit } \\
\text { Semanggi } \\
\text { Lidah mertua } \\
\text { Nusa indah } \\
\text { Tapak dara } \\
\text { Tapak liman } \\
\text { Daun ungu } \\
\text { Lontar } \\
\text { Bunga pagoda } \\
\text { Ketapang }\end{array}$ & $\begin{array}{c}2 \\
9 \\
11 \\
4 \\
9 \\
2 \\
6 \\
1 \\
2 \\
5 \\
3\end{array}$ & $\begin{array}{c}4 \\
50 \\
264 \\
15 \\
10 \\
6 \\
36 \\
3 \\
7 \\
6 \\
3\end{array}$ \\
\hline & & Kebun & $\begin{array}{l}\text { Srigading } \\
\text { Bunga kenop } \\
\text { Sirih belanda } \\
\text { Semanggi } \\
\text { Lotus } \\
\text { Lidah mertua } \\
\text { Kembang sepatu } \\
\text { Ceremai } \\
\text { Kumis kucing } \\
\text { Teratai } \\
\text { Jarak pagar } \\
\text { Kaca piring } \\
\text { Waru } \\
\text { Melati jepang }\end{array}$ & $\begin{array}{l}1 \\
6 \\
1 \\
5 \\
2 \\
3 \\
3 \\
1 \\
4 \\
3 \\
8 \\
2 \\
8 \\
6\end{array}$ & $\begin{array}{c}2 \\
120 \\
2 \\
108 \\
9 \\
17 \\
12 \\
1 \\
9 \\
14 \\
126 \\
11 \\
13 \\
20\end{array}$ \\
\hline & & Tegalan & $\begin{array}{c}\text { Pule pandak } \\
\text { Bunga kenop } \\
\text { Anyang-anyang } \\
\text { Kemuning } \\
\text { Sisik naga } \\
\text { Pulai } \\
\text { Nusa indah } \\
\text { Jarak pagar } \\
\text { Waru }\end{array}$ & $\begin{array}{c}2 \\
4 \\
1 \\
2 \\
4 \\
2 \\
9 \\
12 \\
10\end{array}$ & $\begin{array}{c}4 \\
34 \\
1 \\
5 \\
4 \\
2 \\
12 \\
166 \\
34\end{array}$ \\
\hline
\end{tabular}




\begin{tabular}{|c|c|c|c|c|c|}
\hline No & Kecamatan & Letak & Nama Tanaman & $\begin{array}{c}\text { Banyak } \\
\text { Lokasi } \\
\text { yang } \\
\text { Ditemukan }\end{array}$ & Jumlah Tanaman \\
\hline \multirow[t]{3}{*}{3} & Baturiti & Telajakan & $\begin{array}{l}\text { Melati jepang } \\
\text { Gandarusa } \\
\text { Semanggi } \\
\text { Kadaka }\end{array}$ & $\begin{array}{l}2 \\
6 \\
8 \\
4\end{array}$ & $\begin{array}{c}5 \\
39 \\
185 \\
12\end{array}$ \\
\hline & & Kebun & $\begin{array}{c}\text { Kembang kertas } \\
\text { Bunga kotok } \\
\text { Kenanga } \\
\text { Kadaka } \\
\text { Gandarusa }\end{array}$ & $\begin{array}{l}6 \\
4 \\
6 \\
6 \\
4\end{array}$ & $\begin{array}{l}11 \\
125 \\
28 \\
12 \\
22\end{array}$ \\
\hline & & Tegalan & $\begin{array}{c}\text { Kelor } \\
\text { Awar-awar } \\
\text { Daun encok } \\
\text { Tembelekan } \\
\text { Sirih belanda } \\
\text { Kenanga } \\
\text { Semanggi } \\
\text { Sembung } \\
\text { Daun katu } \\
\text { Tapak liman } \\
\text { Kadaka }\end{array}$ & $\begin{array}{l}1 \\
1 \\
5 \\
6 \\
2 \\
6 \\
7 \\
1 \\
3 \\
3 \\
5\end{array}$ & $\begin{array}{c}3 \\
2 \\
8 \\
19 \\
2 \\
31 \\
170 \\
3 \\
3 \\
5 \\
12\end{array}$ \\
\hline
\end{tabular}

Sumber: Survei

\subsection{Penggunaan Tanaman sebagai Elemen Lansekap}

Tanaman dalam desain lansekap memiliki berbagai macam fungsi, Hasil penelitian ini didukung oleh pernyataan Carpenter et al. (1975) bahwa fungsi tanaman dalam desain pertamanan adalah sebagai tabir untuk mengurangi cahaya matahari dan lampu kendaraan yang menyilaukan dengan cara mengatur tingginya. Selain itu tanaman berfungsi memberi batas untuk privasi, sebagai pengarah, pembentuk ruang, pembatas fisik yang mengarahkan dan mengendalikan pergerakan manusia, hewan dan kendaraan, mengendalikan iklim mikro (suhu, radiasi matahari, angin, presipitasi, kelembaban, mengurangi kecepatan angin dan memberikan naungan), mengendalikan kebisingan, sebagai penyaring dan pengkayaan udara, pengendali erosi dan habitat satwa.

Berikut ini pada Tabel 3.disajikan kegunaan dari tanaman obat sebagai elemen lansekap.

Tabel 3. Kegunaan Tanaman Obat sebagai Elemen Lansekap

\begin{tabular}{cccc}
\hline No & $\begin{array}{c}\text { Kegunaan dalam } \\
\text { lansekap }\end{array}$ & Ketinggian Tempat & Tanaman obat \\
\hline 1. & $\begin{array}{c}\text { Sebagai tabir untuk } \\
\text { mengurangi cahaya matahari } \\
\text { dan lampu kendaraan yang } \\
\text { menyilaukan }\end{array}$ & Dataran Rendah & Angsana, Cempaka putih, Pulai, \\
& Dataran Sedang & Ceremai, Ketapang, Nusa indah, \\
& Dataran Tinggi & Awar-awar,
\end{tabular}




\begin{tabular}{|c|c|c|c|}
\hline No & $\begin{array}{l}\text { Kegunaan dalam } \\
\text { lansekap }\end{array}$ & Ketinggian Tempat & Tanaman obat \\
\hline \multirow[t]{3}{*}{2.} & $\begin{array}{l}\text { Berfungsi sebagai pemberi } \\
\text { batas untuk privasi }\end{array}$ & Dataran Rendah & $\begin{array}{c}\text { Alang-alang, bayam duri, Daun suji, } \\
\text { Hanjuang, Jahe, Langkuas, Pacar cina, } \\
\text { Tapak dara, Widuri }\end{array}$ \\
\hline & & Dataran Sedang & $\begin{array}{l}\text { Bunga kenop, Kacapiring, Kumis } \\
\text { kucing, Srigading, Tapak dara, Waru, }\end{array}$ \\
\hline & & Dataran Tinggi & Tembelekan, \\
\hline \multirow[t]{3}{*}{3.} & Sebagai pengarah & Dataran Rendah & $\begin{array}{l}\text { Kastuba, Kelor, Ketapang, Kol banda, } \\
\text { Lontar, }\end{array}$ \\
\hline & & Dataran Sedang & Anyang-anyang, Lontar, \\
\hline & & Dataran Tinggi & Bunga kotok, Kenanga, \\
\hline \multirow[t]{3}{*}{4.} & Pembentuk ruang & Dataran Rendah & $\begin{array}{l}\text { Adas, Bidara laut, Daun Mangkok, } \\
\text { Daun kentut, Kemuning, Melati jepang, }\end{array}$ \\
\hline & & Dataran Sedang & $\begin{array}{l}\text { Daun ungu, Kemuning, Melati jepang, } \\
\text { Sirih belanda, }\end{array}$ \\
\hline & & Dataran Tinggi & Melati jepang, Sembung, Sirih belanda, \\
\hline \multirow[t]{3}{*}{5.} & Mengendalikan kebisingan & Dataran Rendah & - \\
\hline & & Dataran Sedang & - \\
\hline & & Dataran Tinggi & Daun encok, \\
\hline \multirow[t]{3}{*}{6.} & Penyaring dan penyuplai & Dataran Rendah & Kembang kertas, Lidah mertua, \\
\hline & & Dataran Sedang & Lidah mertua, \\
\hline & & Dataran Tinggi & Kembang kertas, \\
\hline \multirow[t]{3}{*}{7.} & Habitat satwa & Dataran Rendah & Belimbing wuluh \\
\hline & & Dataran Sedang & - \\
\hline & & Dataran Tinggi & - \\
\hline \multirow[t]{3}{*}{8.} & $\begin{array}{c}\text { Pembatas fisik yang } \\
\text { mengarahkan dan } \\
\text { mengendalikan pergerakan }\end{array}$ & Dataran Rendah & $\begin{array}{l}\text { Alamanda, Jarak pagar, Kembang } \\
\text { sepatu, Lili paris, Puring, }\end{array}$ \\
\hline & manusia, hewan, dan & Dataran Sedang & Jarak pagar, Kembang sepatu, \\
\hline & & Dataran Tinggi & Daun katu, Gandarusa, Kelor, \\
\hline \multirow[t]{3}{*}{9.} & Pengendali erosi & Dataran Rendah & Pisang-pisangan, \\
\hline & & Dataran Sedang & - \\
\hline & & Dataran Tinggi & - \\
\hline 10. & Nilai estetika & Dataran Rendah & $\begin{array}{l}\text { Bakung, Bunga kuping gajah, Daun } \\
\text { dewa, Genjer-genjer, Kamboja, Kapu- } \\
\text { kapu, Kembang coklat, Lidah buaya, }\end{array}$ \\
\hline
\end{tabular}




\begin{tabular}{lcc}
\hline No $\quad \begin{array}{c}\text { Kegunaan dalam } \\
\text { lansekap }\end{array}$ & Ketinggian Tempat & Tanaman obat \\
\hline Dataran Sedang & $\begin{array}{c}\text { Lotus, Mawar, Patah tulang, } \\
\text { Bunga pagoda, Lotus, Pule pandak, } \\
\text { Semanggi, Sisik naga, Songgolangit, } \\
\text { Tapak liman, Teratai, } \\
\text { Dataran Tinggi }\end{array}$ & Kadaka, Semanggi, Tapak liman \\
&
\end{tabular}

\section{Simpulan}

Berdasarkan hasil penelitian di lapangan maka dapat ditarik beberapa simpulan antara lain:

1. Dari tempat penelitian yang diinventarisasi telah ditemukan beberapa jenis tanaman obat yaitu antara lain: Kediri 43 jenis tanaman obat, Marga 26 jenis tanaman obat, Baturiti 15 jenis tanaman obat.

2. Habitus dari tanaman obat yang telah ditemukan dibagi menjadi enam yaitu: pohon besar/sedang, pohon kecil/perdu, semak, penutup tanah, tanaman rambat, dan tanaman air.

3. Terdapat 10 kegunaan tanaman obat yang telah diinventarisasi sebagai elemen lansekap yaitu sebagai tabir untuk mengurangi cahaya matahari dan lampu kendaraan yang menyilaukan, memberi batas untuk privasi, sebagai pengarah, pembentuk ruang, pembatas fisik yang mengarahkan dan mengendalikan pergerakan manusia, hewan dan kendaraan, mengendalikan kebisingan, sebagai penyaring dan penyuplai udara, pengendali erosi, habitat satwa, dan sebagai tanaman hias yang memiliki nilai estetika.

\section{Daftar Pustaka}

Adiputra, N. dan S, Handari.2007. Strategi Pelestarian Tanaman Obat dalam Perspektif Budaya.Jurnal bumi lestari.Bagian Fisiologi Fakultas Kedokteran Universitas Udayana.

Carpenter, P.L, T.D Walker, and F.OLanphear. 1975. Plants in the Landscape. W.H.Freeman and Company, San Fransisco.

Hariana, A. 2009. Tumbuhan Obat dan Khasiatnya Seri 1. Penebar Swadaya, Bogor.

Katno dan S. Pramono.2003. Tingkat Manfaat Dan Keamanan Tanaman Obat Dan Obat Tradisional. Balai Penelitian Tanaman Obat Tawangmangu. Fakultas Farmasi, UGM.

Sukandar, E.Y. 2006. Pemanfaatan Obat Tradisional Dengan Pertimbangan Manfaat Dan Keamanannya.Skripsi. Program Studi Farmasi Universitas Jember. 